\title{
Control, controlling and its objectives in the organization
}

\author{
Nina Dědečková ${ }^{1, *}$ \\ ${ }^{1}$ University of Economics in Bratislava, Faculty of Business Management, 85235 Bratislava, Slovak \\ Republic
}

\begin{abstract}
The aim of the paper is to define and compare definitions and objectives of the managerial control and controlling based on research of scientific and professional literature through the opinions of domestic and foreign authors. By studying several domestic and foreign sources, through analogy, analysis, synthesis and comparison, we were able to create an overview of the research areas and defined the basic areas of managerial function of control and controlling. Our finding is that managerial control and controlling is still an actual topic. It is the subject of research by many theorists who focus on defining of these terms. Control is often perceived only as a comparison of two states, ie as the difference between the plan and the reality, while controlling in addition to comparisons also understands controlling as the implementation of corrective actions, thus supporting planning and decision-making. In this paper we identify the opinions of various authors and emphasize the importance of these terms.
\end{abstract}

\section{Introduction}

The business environment in which companies compete for competitive advantage is constantly changing and evolving. Once managers form plans and strategies, they must ensure that the plans are carried out. They must make sure that people are doing what needs to be done and are not doing inappropriate things. The word "control" leads to negative emotions. For many people, control means, above all, constraints, pressure, lack of independence. Managers continually look for ways to improve customer satisfaction, maintain relationships with suppliers, cut inventory costs, and develop the right products. As a result, every organization needs basic systems for allocating financial resources, developing human resources, analyzing financial performance, and evaluating overall profitability. Controlling is the management function in which managers establish and communicate performance standards for people, processes, and devices [2]. Control is defined as any process that directs activities toward organizational goals. It is how effective managers make sure that activities are going as planned. Some managers don't want to admit it, but control problems - the lack of controls or the wrong kinds of controls - frequently cause irreparable damage [1] . Controls should take place at all hierarchical levels of the organizational

\footnotetext{
${ }^{*}$ Corresponding author: nina.dedeckova@euba.sk
} 
structure in order to identify all possible negative impacts on the business. The aim of our paper is to define and compare definitions and objectives of the managerial control and controlling based on the research of scientific literature through the opinions of domestic and foreign authors.

\section{Methods}

Literary review is an important part of the research work because it enriches the research with new knowledge and complements the current state of knowledge. Using literature review, we discuss and compare the views of experts in the perception of the definition of control and its objectives.

Basic scientific methods such as analysis and synthesis, comparison, induction and deduction have been used. Based on the findings, the theoretical basis of the knowledge of the issue was created. All the necessary information on the issue we obtained from the study literature, where a substantial part of the resources were foreign authors. Study literature was available mainly in the form of book publications, but we also drew on various scientific and research works, and we also used scientific articles in magazines.

\section{Results and Discussions}

\section{1 Definition of control and controlling}

The roots of the term control date back to antiquity, when control was applied before the term itself was conceived. The concept of control consists of two Latin words „contra“ and „rotulus“. As reported by Majtan et al. [12], the simple translation can be understood as a counter-effect. At that time, it was written on parchment sheets that were curled into coils. In order to avoid misunderstandings about the original content of the report, parchment sheets were produced in two copies. It was based on these parchments that the correctness and truthfulness of the content of the report was checked. Since then, the term control has spread to all European languages and has become a very popular expression.

During its development it has acquired various meanings and still does not have a generally valid definition. Fayol [6] sees control as a process that begins with setting standards, continues with measuring performance, followed by comparing standards with performance, and taking corrective action in the final phase. Flamholtz [7] asserts, that control is a dynamic management function that has to be constantly adapted to changes in business. Merchant and Van der Stede [14] consider control as a critical management function in organizations, because its failure or neglect can damage the reputation of the company and can cause huge financial losses and, last but not least, the failure of the whole society and bankruptcy. Mockler [16] defines control as a systematic management effort to compare performance with predetermined standards, plans, or objectives whether performance is in line with these standards and presumably to take any remedial action required to see that human and other corporate resources are being used in the most effective and efficient way possible in achieving corporate objectives. Benowitz [2] asserts that organizational control is the process of assigning, evaluating, and regulating resources on an ongoing basis to accomplish an organization's goals.

Sedlák and Lišková [22] understand control as an accompanying phenomenon of planning that completes the overall management process. An essential variable are the plans that inspire action - control. They consider monitoring as the core of the control function and, in the case of the above-mentioned planning, monitoring the progress and compliance with the plan and its objectives. According to Králiček and Molín [10] it is necessary in any 
company and at any control to determine what we control, what meaning of control should be and what benefits or results we expect from the entire control process.

The German word "Kontrolle" was taken from the French "contrôle" or "contrerolle" (central France) in the 18th century. Unlike common definitions of the German term "Kontrolle", the English term "to control" includes not only a comparison of target and actual values, but also perfect control, management and regulation of processes [5]. While the German term "Kontrolle" fulfills its role only until the moment when the controlled facts are compared, the Anglo-American term "to control" is perceived more comprehensively. The term "Kontrolle" is therefore perceived as part of a complex process of control in the AngloAmerican sense [4]. Mäder [11] understands the term Kontrolle as a systematic process of information processing in which two variables are present, which represent realized, required or predicted facts that consider each other. "Kontrolle" is limited to a pure comparison of the target and the actual state. Heuer [9] states that three contents of the term "Kontrolle" were found in German literature by the second half of the 1980s, being traditional, widespread and broadest. Traditional is derived from older German literature. It mainly included a comparison of predetermined and measured values. It was extended by analysis of causes of deviations. The broadest content of the term "Kontrolle", which is underrepresented in German literature, also includes remedial measures. The author draws attention to the fact that many German authors see the difference between "Kontrolle" and "control", because in their view this term means not only carrying out control but also planning at the same time. Therefore, "Kontrolle" is perceived as a subordinate planning process and is dependent on it.

There are some similarities in both languages (English and German). The term control / Kontrolle can acquire two important meanings for our purposes - from both languages we can translate control as comparing the differences between the actual and the desired state. Control can also be translated as to have the ability to control, to have power over something [18].

Later, the term "control" evolved into "controlling". While control refers to the one-time execution of this managerial function during the manager's work, controlling refers to the regular application of control in the enterprise. Control is considered to be a one-off act that captures the specific steps of the control process as well as the factors affecting that act. According to Mišún and Mišúnová [15] control is an ongoing process of drafting standards, measuring performance, benchmarking, and taking corrective actions to ensure effective and efficient activities within an organization. As Lester Bittel noted, controlling is the function that brings the management cycle full circle. It is the steering mechanism that links all the preceding functions of organizing, staffing, and leading to the goals of planning. The planning process determines the goals and objectives that eventually become the foundation of controls [19].

Robbins and Coulter [20] define controlling as a process of monitoring, comparing, and correcting work performance. All managers should control even if their units are performing as planned because they can't really know that unless they've evaluated what activities have been done and compared actual performance against the desired standard. Effective controls ensure that activities are completed in ways that lead to the attainment of goals. Whether controls are effective, then, is determined by how well they help employees and managers achieve their goals. Schermerhorn and Bach [21] explained, how does control fit in with the other management functions. Planning sets the direction of organization, organizing arranges people and resources for work, leading inspires people to put forth their best efforts and controlling sees to it that the right things happen, in the right way, and at the right time. If things go wrong, control helps to get things back on track.

Despite the diverse definitions of control, many have common characteristics. These basic common features include [23]: 
Table 1. Characteristics of control.

\begin{tabular}{|c|c|}
\hline Universality & $\begin{array}{l}\text { The control process is one and the same } \\
\text { time irrespective of the type of organization } \\
\text { or function to be controlled. It is the } \\
\text { foremost responsibility of a manager to } \\
\text { regulate the operations on an on-going basis } \\
\text { and keep the operation focused on goal } \\
\text { accomplishments. }\end{array}$ \\
\hline Continuity & $\begin{array}{l}\text { Planning is a perpetual process. Koontz } \\
\text { compares the control function to a navigator } \\
\text { who takes readings to ascertain where it is } \\
\text { related to a planned course. Likewise, a } \\
\text { business manager has to constantly ensure } \\
\text { that the enterprise is on course. It requires } \\
\text { constant review and revision in response to } \\
\text { behavior of environmental variables. Thus, } \\
\text { it is not a one-time affair. }\end{array}$ \\
\hline Dynamism & $\begin{array}{l}\text { Control function needs to be changed in } \\
\text { response to change in plans, objectives and } \\
\text { to behavior of environmental variables. } \\
\text { Therefore, it is a dynamic function. }\end{array}$ \\
\hline Omnipresence & $\begin{array}{l}\text { Managers across the levels, right from the } \\
\text { CEO down to the first line supervisor, } \\
\text { exercise control function. The nature, scope } \\
\text { and limit of control functions vary. For } \\
\text { example, top management is engaged in } \\
\text { exercising strategic control, middle level } \\
\text { managers are involved in tactical control } \\
\text { and those at lower echelons are exercising } \\
\text { operational control. }\end{array}$ \\
\hline Future & $\begin{array}{l}\text { Managers cannot control the past. But the } \\
\text { benefits of bitter and better experiences of } \\
\text { the past can be helpful in shaping a fruitful } \\
\text { course of action in future. Preventive } \\
\text { control guards against future loss, wastage } \\
\text { and deficiency or deviation. }\end{array}$ \\
\hline Final function & $\begin{array}{l}\text { It follows all other functions. Planning is the } \\
\text { basic function control. It is indispensable } \\
\text { for ensuring accomplishment of } \\
\text { organizational goals. It requires } \\
\text { measurements of actual performance and } \\
\text { comparing it against the pre-fixed } \\
\text { standards. Deviation, if any, is addressed to } \\
\text { reach level of desired performance. Thus, } \\
\text { control is linked with other managerial } \\
\text { functions. }\end{array}$ \\
\hline
\end{tabular}




\section{Influencing}

Control is supposed to structure the events and to condition the behavior. It is aimed at curbing undesirable behavior and shaping the pattern of future events. It includes people to conform to certain norms and standards.

\subsection{Control Objectives}

Mullins [17] considers control as one of the essential features of managerial work. Traditional views of control placed emphasis on the need for conformity of activities with the organization. Tannenbaum, for example, sees control as an inherent characteristic of the nature of organizations. The process of control is at the center of the exchange between the benefits that the individual derives from membership of an organization and the costs of such benefits. Organization implies control. It is the function of control to bring about conformance to organizational requirements and achievement of the ultimate purposes of the organization.

Boddy [3] asserts, that control has many positive meanings - standing for order, predictability or reliability. If things are under control, suppliers know what to deliver and when, people know what they are expected to do, customers know when to expect a delivery, staff know they will be paid. In this sense, control is an essential part of organizational life, because it helps to ensure that cooperative work by many people and units collectively adds value to resources. An absence of such control implies uncertainty, chaos, inefficiency and waste - an organization that is destroying, rather than enhancing, value. Hansen [8] considers feedback to be an important element of control. Feedback is information that can be used to evaluate or correct the steps taken to implement a plan. Based on the feedback, the manager or worker may decide to let implementation continue as it is, take corrective actions of a certain type to bring the activities back to compliance with the original plan, or to adjust the standards. Hansen considers feedback to be a critical part of the control function. Fayol [6] states that the aim of control is to point out errors that need to be corrected and prevented. As in the definition of Fayol himself, Mockler [16] considers that the objective of control is to take corrective action to ensure that business objectives are met as effectively as possible.

According to Robbins and Coulter [20] managers that didn't use control, they have no way of knowing whether their goals and plans were being achieved and what future actions to take. The second reason controlling is important is because of employee empowerment. Many managers are reluctant to empower their employees because they fear something will go wrong for which they would be held responsible. But an effective control system can provide information and feedback on employee performance and minimize the chance of potential problems. The final reason why managers control is to protect the organization and its assets. Today's environment brings heightened threats from natural disasters, financial scandals, workplace violence, global supply chain disruptions, security breaches. Managers must protect organizational assets if any of these things should happen. Comprehensive controls and back-up plans will help assure minimal work disruptions.

Tripathi and Reddy [24] defined the main objectives of control as increasing productivity, reducing mistakes and defects, facilitating communication, improving safety or reducing costs.

Benowitz [2] states that organizational control is the process of assigning, evaluating, and regulating resources on an ongoing basis to accomplish an organization's goals. The main purposes of control, inspired by Benowitz are shown in Table 2: 
Table 2. Purposes of control.

\begin{tabular}{|c|c|}
\hline Effectiveness of plans & $\begin{array}{l}\text { Managers need to measure progress, offer } \\
\text { feedback, and direct their teams if they } \\
\text { want to succeed. }\end{array}$ \\
\hline Consistency of organizational activities & $\begin{array}{l}\text { Policies and procedures help ensure that } \\
\text { efforts are integrated. }\end{array}$ \\
\hline Effectiveness of organization & $\begin{array}{l}\text { Organizations need controls in place if they } \\
\text { want to achieve and accomplish their } \\
\text { objectives. Effectiveness is a measure of } \\
\text { how well the outcomes of an activity relate } \\
\text { to the broader objectives of the unit - that } \\
\text { is, how well it supports the achievement of } \\
\text { broader goals. }\end{array}$ \\
\hline Efficiency of organization & $\begin{array}{l}\text { Efficiency probably depends more on } \\
\text { controls than any other management } \\
\text { function. It is widely used to show how } \\
\text { productive a unit is, and how well people } \\
\text { have managed it - the more output for the } \\
\text { fewer inputs, the better, since that implies } \\
\text { that value is being added to the resources. }\end{array}$ \\
\hline Feedback & $\begin{array}{l}\text { Not only do they measure progress, but } \\
\text { controls also provide feedback to } \\
\text { participants as well. Feedback influences } \\
\text { behavior and is an essential ingredient in } \\
\text { the control process. }\end{array}$ \\
\hline Support for decision making & $\begin{array}{l}\text { The ultimate purpose of controls is to help } \\
\text { managers make better decisions. Controls } \\
\text { make managers aware of problems and give } \\
\text { them information that is necessary for } \\
\text { decision making. }\end{array}$ \\
\hline
\end{tabular}

In some organizations, efficiency and cost savings have become primary goals. When this happens, the mission of an organization can become obliterated - noble goals such as providing safe vehicles, safe workplaces, and contributing to society take a backseat to maximizing human and organizational output and financial results. Second, when controls become the goal rather than an enabler of organizational success, organizational cultures can become toxic. In companies where people are constantly under pressure and stressed, it is difficult to sustain creativity and innovation, and people are often not able to do and be their best. Having said all this, the need of controls in organizations is obvious. Organizations 
welcome ways to work more efficiently, and all leaders want to produce quality products and services [13].

According to Williams [25] people may have objectives imposed on them, they may set them for themselves, or they may sit somewhere between those two extremes. Regardless of the situation, it will be needed to ensure that objectives and those you set for your team are sufficiently detailed and complete for you to know exactly what you and they are expected to achieve. To be truly useful objectives should be SMART, which means Specific, Measurable, Agreed, Realistic and Time-based. In other words, the outputs should be clearly defined such that performance can be quantified, agreed between employee and the organization, achievable within the constraints of time and resources and with a target date so that achievement can be measured. There are obvious motivational and practical reasons why objectives should be agreed and realistic. The SMART definition places so much emphasis on quantified and measurable objectives. That is because objectives are of little value on their own. They only become valuable as a basis for measuring performance.

\section{Conclusion}

At the end of the paper we state that managerial control at all levels of the management of organization is still an actual topic. It is the subject of research by many theorists who focus on defining the managerial control and its objectives. Control is a critical function within any organization because negative or even disastrous consequences can be associated with not meeting the established standards of performance. For example, poor inventory control can result in lost business because of a product shortage. Poor quality control may result in angry customers, lost business, and the necessity to provide customers with replacement products. Poor cost control can lead to negative profitability and perhaps even bankruptcy. The list of potential control problems is almost limitless. These problems all point to the fact that improving operational effectiveness and quality is virtually impossible without stringent control mechanisms. Except for very small organizations, the need for control is ubiquitous. Some people even claim that management shouldn't exercise any form of control whatsoever and should only support employee efforts to be fully productive members of organizations and communities. Along those same lines, some experts even use the word "coordinating" in place of "controlling" to avoid sounding coercive. All managers exercise control as they try to add value by transforming resources into outputs of greater value. However thoroughly they plan their objectives and how to meet them, internal and external events intervene. So, they need to supplement the activity of planning with that of controlling - checking that work is going to plan, and if necessary, taking corrective action. The sooner they note deviations, the easier it is to bring performance into line with the plan.

\section{Acknowledgements}

This article is a partial output of the research project of VEGA no. 1/0017/20 entitled „Changes in the application of managerial functions in the context of the fourth industrial revolution and adaptation processes of enterprises in Slovakia.“" 


\section{References}

1. T. S. Bateman, S. A. Snell, R. Konopaske, Management: Leading \& Collaborating in a Competitive World. (2019)

2. E. Benowitz, Cliffsquickreview. Principles of management. (2001)

3. D. Boddy, Management: an introduction. (2008)

4. R. Bramsemann, Controlling, 2. (1980)

5. C. Endenich, Comparative Management Accounting: ein Vergleich der Controllingforschung und-praxis in Deutschland und Spanien. p. 100. (2012)

6. H. Fayol, General and industrial management, trans. (1949)

7. E. Flamholtz, Effective management control: theory and practice. (1996)

8. D. R. Hansen, M. M. Mowen, Managerial accounting 8th edition. (2007)

9. M.F. Heuer, Kontrolle und Steuerung der Materialwirtschaft. (1988)

10. V. Králiček, J. Molín, Vnější a vnitřni kontrola z pohledu managementu. (2014)

11. O. B. Mäder, Controlling klipp \& klar. (2018)

12. M. Majtán and col, Manažment. (2003)

13. A. McKee, Management: A Focus on Leaders. (2012)

14. K. A. Merchant, W. A. Van Der Stede, Management Control Systems: Performance Measurement, Evaluation and Incentives. (2007)

15. J. Mišún, I. Mišúnová-Hudáková, Kontrolovanie v manažmente. (2017)

16. J.R. Mockler, Readings in Management Control. (1970)

17. L. J. Mullins, Management \& Organisational Behaviour. (2016)

18. D. Otley, K. Merchant, C. Emmanuel, Accounting for Management Control. (2013)

19. W. R. Plunkett, G. S. Allen, R. F. Attner, Management. (2008)

20. S. P. Robbins, M. Coulter, Management. Vol. 14, 752 (2017)

21. J. R. Schermerhorn, D.G. Bachrach, Exploring Management. (2018)

22. M. Sedlák, C. Lišková, Manažment. (2016)

23. K. Sundar, Principles of Management. (2013)

24. P. C. Tripathi, P. N. Reddy, Principles of Management. (2012)

25. K. Williams, B. Johnson, Introducing management: A development guide. (2003) 